\title{
Math Modeling and Case Solving in Real Context: Case Study at Xuan Giang High School, Soc Son District, Hanoi City, Vietnam
}

\author{
Tran Viet Cuong ${ }^{1, *}$, Le Hong Quang ${ }^{2}$ \\ ${ }^{1}$ Department of Training, Thai Nguyen University of Education, Vietnam \\ ${ }^{2}$ Department of Mathematics and Informatics, Xuan Giang High School, Soc Son District, Hanoi City, Vietnam
}

Received August 2, 2020; Revised October 6, 2020; Accepted October 19, 2020

\section{Cite This Paper in the following Citation Styles}

(a): [1] Tran Viet Cuong, Le Hong Quang, "Math Modeling and Case Solving in Real Context: Case Study at Xuan Giang High School, Soc Son District, Hanoi City, Vietnam," Universal Journal of Educational Research, Vol. 8, No. 11B, pp. 6229 - 6238, 2020. DOI: 10.13189/ujer.2020.082261.

(b): Tran Viet Cuong, Le Hong Quang (2020). Math Modeling and Case Solving in Real Context: Case Study at Xuan Giang High School, Soc Son District, Hanoi City, Vietnam. Universal Journal of Educational Research, 8(11B), 6229 6238. DOI: 10.13189/ujer.2020.082261.

Copyright $\bigcirc 2020$ by authors, all rights reserved. Authors agree that this article remains permanently open access under the terms of the Creative Commons Attribution License 4.0 International License

\begin{abstract}
Research Objectives: Assess students' process of problem-solving situations in real contexts, through selection and evaluation of solutions to see whether the solutions they offer are really applicable in real-world contexts. Research Methods: We chose the first group of 3 students who have been taught by teachers the method of mathematical modeling; the second group of 3 students did not learn about mathematical modeling. Content 1: Teachers prepare some problematic situations in the real world, students perform problem solving; Content 2: we ask the teacher to create conditions for students to search for problematic situations themselves in real contexts, students solve problem. Research result: We found that, in the first group, students significantly increased their mathematical modeling ability, they could easily identify problematic situations; convert from life language into mathematical language. Moreover, students in the first group not only offer solutions to solve mathematical problems, they also consider, evaluate solutions, consider whether this mathematical result is converted to practical and applied in context. Students are confident in communicating; proposing ideas for model improvement, changing solutions, finding the most acceptable options in practice. On the other hand, 3 students of the second group had difficulty in solving problems. The students were mainly dealing with situations that were purely mathematical, lack of creativity when
\end{abstract}

proposing solutions, as well as not yet considered whether the solution is appropriate in the practical context or not.

\begin{abstract}
Keywords Mathematic Modeling, Theoretical Perspectives, Real Life Problem Solving
\end{abstract}

\section{Introduction}

Mathematics is always present in the lives all around us. The mathematics laws are clearly visible all over the world, including in nature, and the problem-solving skills gained from completing math exercises can help us solve problems in other areas of life. Although many people may complain that math is boring or complicated, math in fact plays a very important role in our lives.

In the changing world conditions, what we basically expect from our students is to deal with the problems they face in life, creatively think and analysis.

Effective math instruction requires an active role from the student and the teacher. The teacher's goal is to provide opportunities for all students to have a diverse and enriching learning experience. Teaching in Teaching Mathematics addresses the individual needs of students. The Mathematics curriculum focuses heavily on the student's active role in learning Math (see Pehkonen \& 
Rossi 2007).

In recent years, general education in Vietnam has focused more on helping students know how to apply mathematics in solving practical situations. Specifically, there have been changes in Vietnam's Mathematics curriculum and textbooks.

For example, for Grade 9 Math (teacher book) clearly states: "Perspectives of increasing practicality, pedagogy is clearly shown in the 2002 program, creating conditions for students to increase practice and computational skills and mathematical knowledge application to life and other subjects”.

Similarly, the high school Math curriculum also emphasizes this point of view, "The program is built and developed according to the following points of view: Select basic, update, systematical and practical math knowledge in a streamlined direction which is suitable to students' cognitive levels, demonstrating inter-disciplinarity and integration of educational contents, demonstrating the instrumental role of mathematics; Strengthen practice and apply, practice teaching math associated with practice. The first goal of the program needs to be achieved is that mathematical knowledge can be applied to life, and to support other subjects".

A mathematical model is a problem-solving solution in which real-life situations are represented by mathematics. The things learned in math courses may not leave a deep impression on students, unless they are used in everyday life or are part of student life [1], which leads to the lack of adequate development of systematic and advanced thinking abilities in individuals, while in the changing world, the basic characteristics of a student are to be an active user of knowledge and can solve any problems they encounter at any stage of life using such thinking skills. Modeling is one of the most widely studied topics by math educators [2], [3], [4]. Students are expected to assess their passion, interests, experience and talents to improve each person's development every day. This is extremely helpful for students pursuing their future aspirations after graduation [5], [15].

The general trend is that advanced math education in the world not only assesses knowledge but also examines students' ability to apply their knowledge and experience in practical problems and What can be done on the basis of the knowledge learned [6], [7]. Specifically, it focuses on the ability to use the knowledge learned in practice and the capacity to handle situations that students will encounter in life after leaving school. To apply mathematical knowledge in solving real-world situations, one has to mathematicalize the situation. It means building an appropriate mathematical model that allows finding answers.

Therefore, right from the stage of intermediate, teachers need to formulate modeling skills through teaching Math [8], [9]. Modeling in teaching Math is a process that helps students learn and explore real life situations by using mathematical tools and languages. Using this process in teaching will help teachers develop students' learning activeness, allowing them to answer the question "What application of math in practice and what the role of math in explaining practical phenomena is?” [2], [10]. This has a great meaning in inspiring early learning motivation for students. Many studies [11] have shown that clarifying the relationship between mathematics and practice will help teachers to create more positive Situations and learning activities to students. Furthermore, by participating in modelling activities, the students would develop their problem-solving skills and regularly adjust their thinking [12].

Students need to thrive on their ability to handle real-world situations [13], [14]. Therefore, it is very necessary for students to evaluate and select solutions. Because sometimes, that solution is only suitable for calculating in theory, but in practice it is not possible. Finding a reasonable solution for solving problems from the real context is necessary, and then the learning of student is really meaningful.

In order to carry out the trial, the author and the teacher had a direct discussion, so the teacher grasped the purpose of the experimentation.

\section{Research Methods}

\subsection{Objective and Content of the Experimentation}

\section{Objective of the experimentation}

To collect information about students' ability of assessment and solutions selection through activities of solving some problematic situations in real context.

\section{Content of the experimentation}

Content 1: Teachers prepare a number of problematic situations in the real world; students perform problem solving

Content 2: The author has asked the teacher to create conditions for students to search for problematic situations by themselves in real contexts; students solve problems.

\subsection{Test Method}

Participants: 03 students (Class 10A, Xuan Giang High School, Soc Son District, Hanoi City, Vietnam, taught by Mr. Le Hong Nam in Mathematics) (Group 1) affected by the measure. The author proposes, students work together to solve the task in content 1 ; In content 2, the group seeks out situations in real context to solve.

03 students (Class 10C, Xuan Giang High School, Soc Son district, Hanoi, Vietnam taught by Mr. Do Thanh Son in Mathematics) are not affected by any measures proposed by the author at This study (Group 2).

As follows: 
Table 1. Information about students participating in the experimentation

\begin{tabular}{|c|c|}
\hline Students' names, Class, School & Remarks \\
\hline $\begin{array}{l}\text { Group } 1 \\
\text { Nguyen Van An, Class 10A, Xuân } \\
\text { Giang High school; } \\
\text { Nguyen Thi Thuyen, Class 10A, } \\
\text { Xuan Giang High school; } \\
\text { Truong Thi Yen, Class 10A, Xuan } \\
\text { Giang High school. }\end{array}$ & $\begin{array}{l}\text { Be affected by the proposed } \\
\text { measure } \\
\text { Teacher: Mr. Le Hong Nam }\end{array}$ \\
\hline $\begin{array}{l}\text { Group } 2 \\
\text { Do Ba Khanh, Class 10C, Xuan } \\
\text { Giang High school; } \\
\text { Nguyen Thi Minh Phi, Class 10C, } \\
\text { Xuan Giang High school; } \\
\text { Nguyen Duc Kien, Class 10C, Xuan } \\
\text { Giang High school. }\end{array}$ & $\begin{array}{l}\text { Not be affected by the } \\
\text { proposed measure Teacher: } \\
\text { Mr. Do Thanh Son }\end{array}$ \\
\hline
\end{tabular}

With the help of the Math and Informatics Group, along with the help of Mr. Le Hong Nam who directly teaches Math, the method proposed by the author was implemented during the teaching of Math at Class 10A (from March 2019 to April 2019). The author has discussed with Mr. Le Hong Nam about the experimentation and would like to get an accurate assessment of students 'mathematical modeling capabilities through students' ability to evaluate and select solutions. The selection of these three students was chosen by Mr. Le Hong Nam with the criteria of loving to study math, voluntarily participate in experiments, and enough time.

Similarly for the three students from the group not affected by the method proposed by the author in this study, the teacher- Mr. Do Thanh Son, also helped the author choose 03 students with the same criteria as the students who were affected by measures.
The author and teachers have agreed on the time for experimentation is 05 days, starting from the 2nd day and ending on the 6th day (specifically: Monday, $18^{\text {th }}$ March, 2019 to Friday, 24 ${ }^{\text {th }}$ March, 2019).

\subsection{Evaluation Tool}

The author and the teacher who are an assistant for the experimentation agreed to use a same Rubic sample to evaluate. After the experiment period, teachers use the Rubic worksheet below to find out what their students have done and to what extent, thereby assessing each student's ability to model Mathematics.

Table 2. Rubic - Assess students' mathematical modeling competence

\begin{tabular}{|c|l|l|l|l|}
\hline & Excellent & Good & Average & $\begin{array}{c}\text { Keep } \\
\text { trying }\end{array}$ \\
\hline $\begin{array}{c}\text { Convert life language } \\
\text { into math and vice } \\
\text { versa }\end{array}$ & & & & \\
\hline $\begin{array}{c}\text { Apply mathematical } \\
\text { knowledge in the steps } \\
\text { of mathematical } \\
\text { modeling }\end{array}$ & & & & \\
\hline $\begin{array}{c}\text { Choose a } \\
\text { problem-solving } \\
\text { strategy }\end{array}$ & & & & \\
\hline $\begin{array}{c}\text { Evaluate mathematical } \\
\text { solutions with } \\
\text { practical requirements }\end{array}$ & & & & \\
\hline Present & & & & \\
\hline Overall evaluation: & & & \\
\hline
\end{tabular}




\section{NOTE FOR EXPERIMENTATION}

\section{NOTE 1: PROBLEMS IN THE REAL CONTEXT}

(Students think and find solutions to solve tasks that can be applied well in practice, then explain to everyone why you choose that solution)

Case 1. (Planting) The director of $X$ Company has just inaugurated his house, the area of the land to build house is $600 \mathrm{~m}^{2}$, and $95 \mathrm{~m}$ of iron mesh was used to make a fence. Now he wants to plant trees and flowers to make the house more beautiful. In his opinion, Cedrus trees will be planted along the house, Bonsai bamboo will be planted in front of and behind the house. The distance between each bonsai must be technical. If you take on this task, how you will do it (know that the length of entrance gate is $5 \mathrm{~m}$ ), the garden of the house is rectangular.

Case 2. (Painting the door) Two workers were tasked with painting a wall. After $t$ did 7 working hours of the first worker and 4 working hours of the second person, they painted $\frac{5}{9}$ the wall. Then they started to work together in 4 hours, after that only $\frac{1}{18}$ of the wall wasn't completed. Because both of them were busy, they asked the third worker to paint the rest of the wall. Now we have to divide their wages equally, knowing that the painting fee for the whole wall is $360000 \mathrm{VND}$.

\section{NOTE 2: SUGGESTIONS OF PROBLEMS IN THE REAL CONTEXT AND RESOLUTION}

(Identify one or a few problematic situations in real life, then propose the solution)

\subsection{Analysis and Discussion}

In this study, we evaluate the process of solving each case in turn (considering how to solve and the performance of each group). The evaluation process is exchanged, criticized by teachers and students, considered from math results to practical results, from there, making comments for each solution and directions to overcome difficulties. This approach is currently not popular in Vietnam because the framework program is concretized in each class period; teachers and students are difficult to implement activities frequently as suggested in the study. Here, we consider the explanation in each situation for group 1 and group 2 .

\section{* CASE 1}

This is a practical problem, students are not familiar with or know the algorithm when studying in class. Students need to use relevant mathematical knowledge and experience to find solutions. Students need to calculate the number of plants to grow in the garden following the intention of the employer. So, we need to pay attention to the distance of each type of bonsai, the length and the width of the garden.

\section{Group 1:}

Solution description: Firstly, students drew a problem description, discussed and agreed on how to do it. They all thought that it was necessary to find the distance between each side of the garden, if they could find the distance between each side of the garden, then they could plant trees.

The distance between each edge can be well calculated by students by applying mathematical knowledge such as: area calculation, perimeter of rectangle, solution of quadratic equation. The following is a description of how to calculate the edges of the garden that group 1 found.

The next activity is to calculate the amount of each type of tree to buy for planting. Some ideas were given as follows:

Truong Thi Yen was tasked with learning about Cedrus trees and bamboo, and the best suited distance to plant each tree. She was advised that she should keep the distance between the trees at least $2 \mathrm{~m}$ to ensure soil nutrition and light for plants (Figure 1a, b.). 


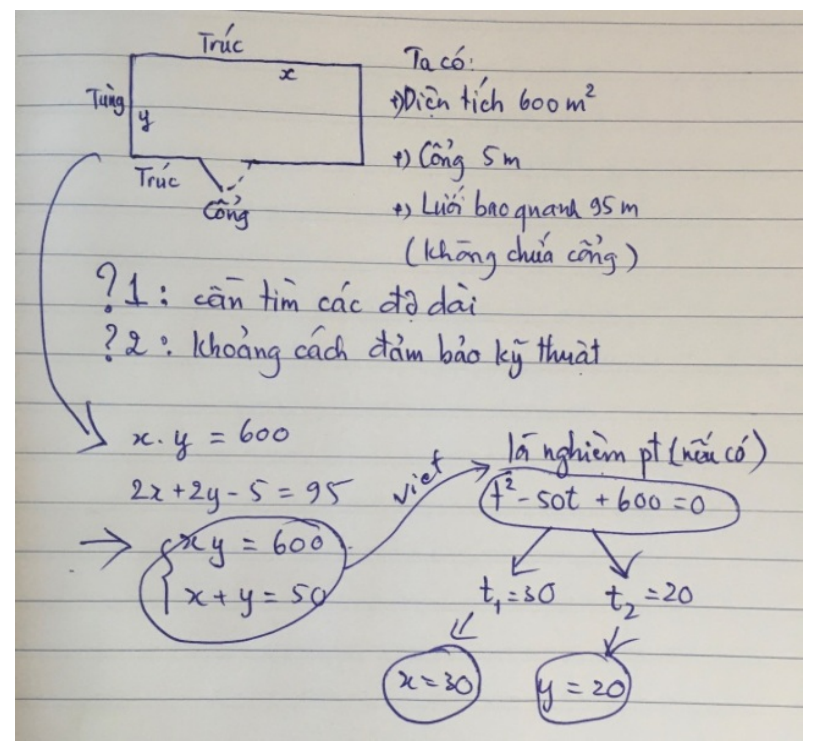

Figure 1a. Some solutions description by Group 1 (Case 1)

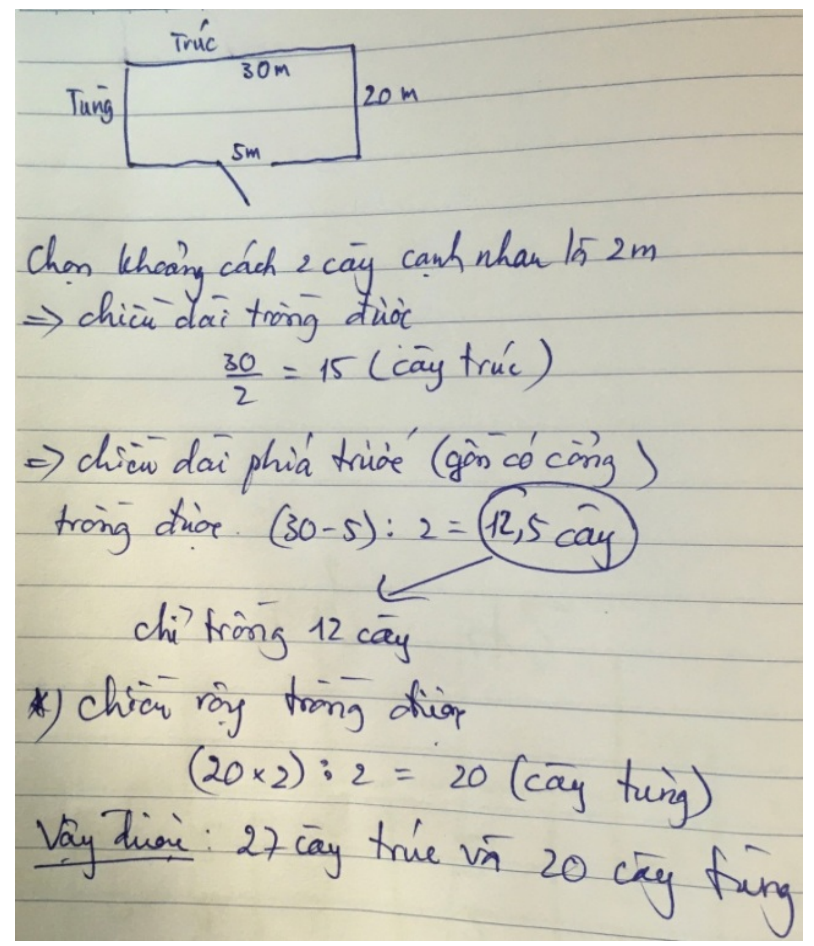

Figure 1b. Some solutions description by Group 1 (Case 1)

The group then agreed that both plants were planted so that the distance between the two trees was $2 \mathrm{~m}$.

Next, the whole team discussed the solution:

- Nguyen Van An said that this solution was inaccurate, last week he went to home town and was assigned to irrigate cabbage gardens by the grandparents (small and rectangular garden), and An noticed that if the distance between trees is the same, at the corners of the garden, it should be counted only once (not counted as trees in the other right-hand side).

- Nguyen Thi Thuyen said that, if the position of the garden gate is different, maybe the number of plants in front of the garden is also different, for example, a side of the gate is less than $2 \mathrm{~m}$ from one corner of the garden corner (such as $1.8 \mathrm{~m}$ ).

In the end, three students agreed that the results from mathematical calculations are not always consistent with real life (Figure 2.).

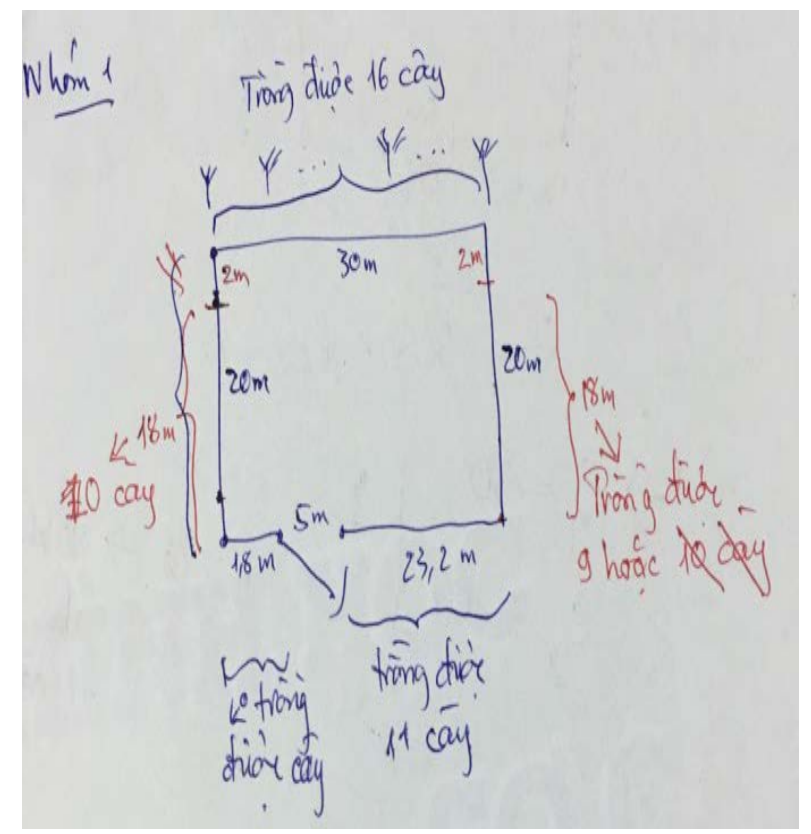

Figure 2. Solution description by Group 1 (Case 1)

Solution:

The long edge of the garden (back) planted 16 bamboo trees (because 30: $2+1=16$ ) including both ends of the edge.

The long front edge of the garden planted 11 bamboo trees.

9 Cedrus trees and 10 Cedrus trees were planted on the two sides of the garden

Conclusion: 19 Cedrus trees and 27 bamboos should be bought

However, group 1 still stated that the reality may be different because of the gate position, and which type of tree would be planted or not planted at the corner of the garden.

\section{Group 2:}

The first solution that Group 2 proposed: they said that in the time to solve the situation, they negotiated to the buyer that after planting, if redundant, the trees would be returned to the shop (commit the tree is still alive). After planting trees on demand, they would count the number of trees of each type and make a report.

However, there are still two people who disagreed with this solution. Khanh, Phi and Kien suggested using math to calculate the length of the garden, and then divide by the distance of the trees to determine the number of trees to buy (Figure 3.). 


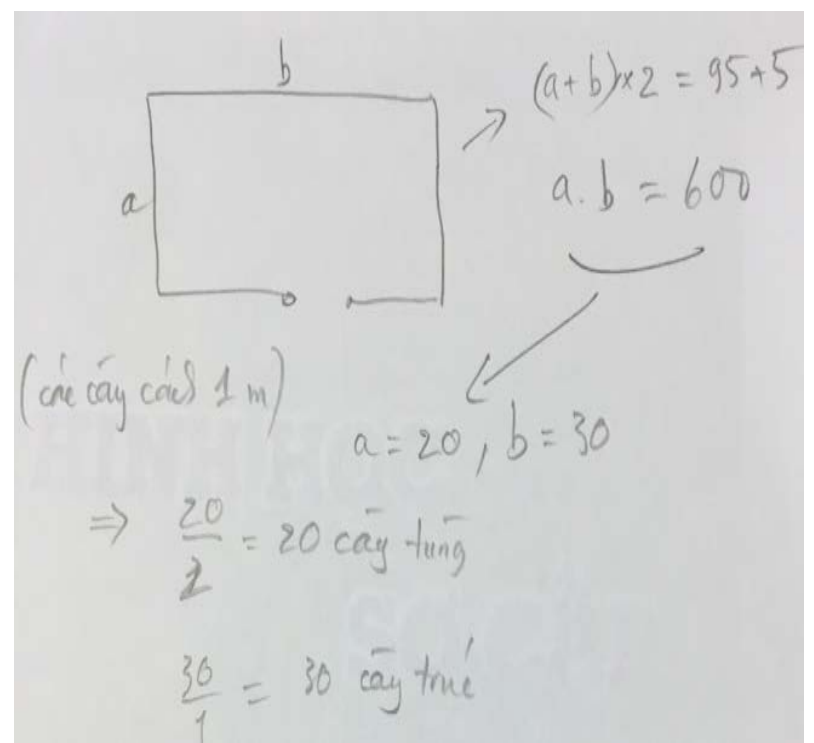

Figure 3. Solution description by Group 2 (Case 1)

Specifically, the solution of Group 2:

If $a$ is the length of the garden and $b$ is the width of the garden,

$$
\text { We have: }\left\{\begin{array}{c}
a+b=\frac{95+5}{2}=50 \\
a b=600
\end{array}\right.
$$

According to the "Viet" theorem, $a, b$ are solutions of the equation: $m^{2}-50 m+600=0$

$$
\leftrightarrow\left\{\begin{array} { l } 
{ m _ { 1 } = 3 0 } \\
{ m _ { 2 } = 2 0 }
\end{array} \rightarrow \left\{\begin{array}{l}
b=30 \\
a=20
\end{array}\right.\right.
$$

Group 2 chose $1 \mathrm{~m}$ to be the distance between trees side by side

So the number of Cedrus trees to plant is: $2 \cdot \frac{20}{1}=40$ (Cedrus tree)

So the number of bamboos to plant is: $\frac{30+25}{1}=55$ (bamboo)

Growers do not need to calculate but buy randomly a certain number of trees and plant them according to the technical distance of the bonsai, if lacking trees, buy more, if left over, return it to the place of sale. We see that with such a way of working, they will be very hard and will incur additional transportation costs to buy or return the trees if the house is far away from the shop.

\section{* CASE 2}

\section{Group 1:}

The problem is that how to calculate the amount that each person receives after painting the wall. To solve this problem, we must concern to the time and the amount of work.

\section{Students seek resolution:}

Solution 1: Calculating by the number of working hours
An and Thuyen's suggestion: the third person doing 1/18 of task, so the amount of money that he will receive will be the total amount divided by 18 . Thus, the third person will receive 20,000 VND.

The remaining amount of the first and second ones will be VND 340,000, and then we need to calculate their wages according to the number of working hours of each person.

Therefore, the first person worked for 11 hours should receive: $(340,000 / 19) * 11=197,000 \mathrm{VND}$.

The second one will receive the rest equal to: $340,000-197,000=143,000$ VND (Figure 4.)

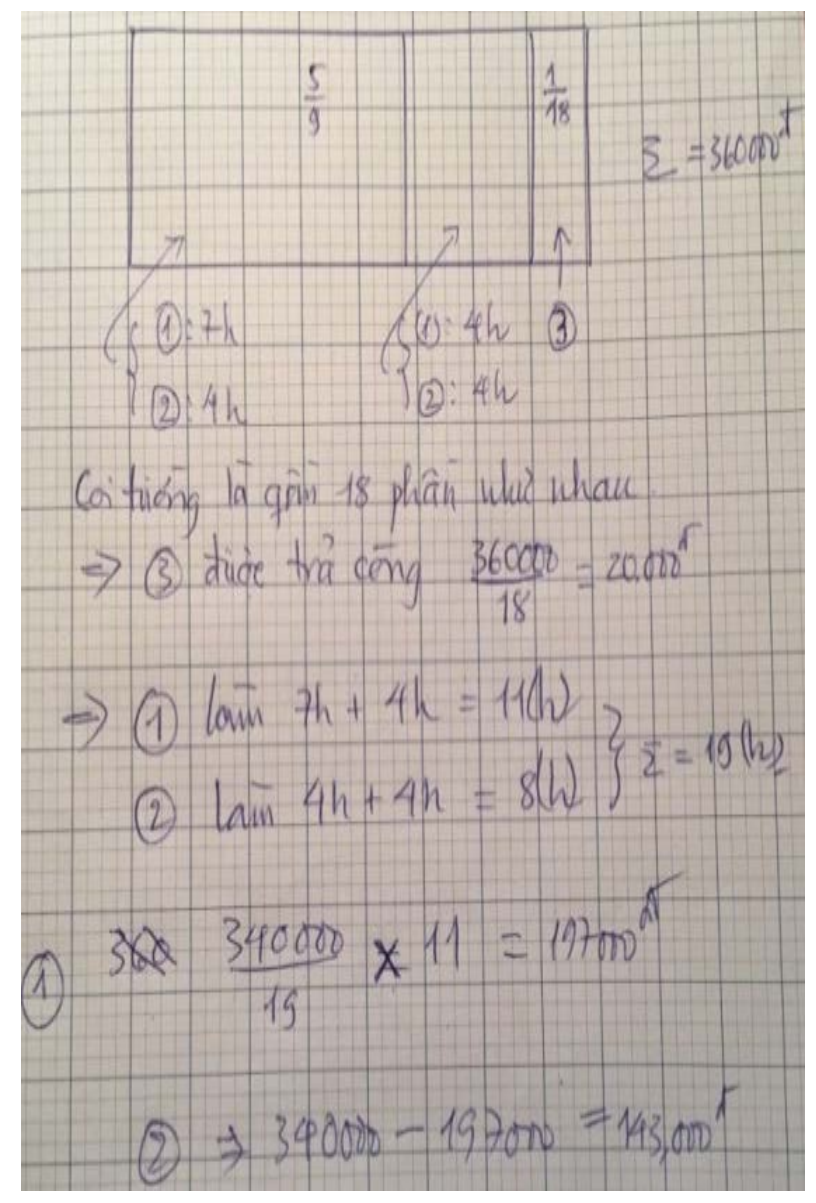

Figure 4. Some solutions description by Group 1 (Case 2)

However, after taking this solution, all three of them find it hard to because the wages depend on the outcome of the task. This conflict led to the next solution of Group 1.

\section{Solution 2: Calculating according to the work done}

The salary of the third person is 200,000 VND

Ta chỉ quan tâm đến tiền công mà người công nhân thứ nhất và thứ hai có thể nhận được.

We just concern about the wages that the first and second workers can receive.

Assuming the capacity of each person is constant when working, if $x$ is the wall of the first person to do in 1 hour, $y$ is part of the second person doing in 1 hour 
According to the topic we have: $\left\{\begin{array}{l}7 x+4 y=\frac{5}{9} \\ 4 x+4 y=\frac{7}{18}\end{array} \rightarrow\right.$ $\left\{\begin{array}{l}x=\frac{1}{18} \\ y=\frac{1}{24}\end{array}\right.$

So the first person will complete $\frac{11}{18}$ of the task

The amount of money that the first person will receive is $\frac{11}{18} \cdot 360000=220000 \mathrm{VND}$

The second person will complete $8 \cdot \frac{1}{24}=\frac{1}{3}$ of the task

The amount of money that the second person will receive is $\frac{1}{3} \cdot 360000=120000 \mathrm{VND}$

So in this task, the amount that the first, second and third workers receive sequentially are: $220000 \mathrm{VND}, 120000$ VND, and 20000 VND (Figure 5.)

Explanation of Group 1: After solving case 2 in two ways, the whole group considered and realized that it is more reasonable to use each person's paint productivity. Because in fact, each worker will have different productivity, we should not consider the same productivity, which will lead to unfair labor pay.

Students use mathematical modeling to solve situations, and moreover, students know how to choose solutions that are appropriate in real life.

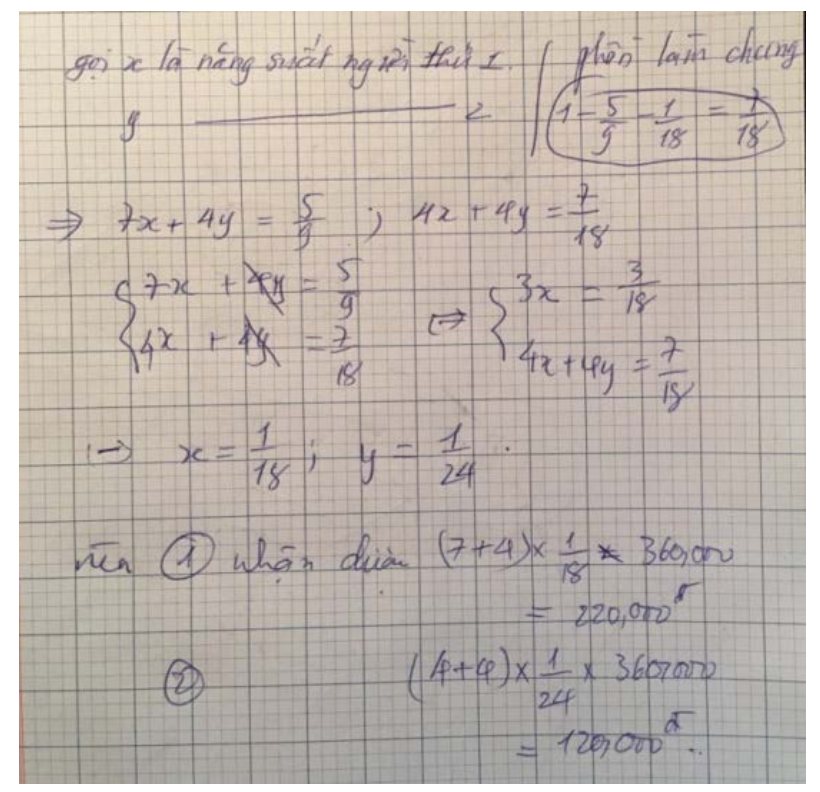

Figure 5. Other solution description by Group 1 (Case 2)

\section{Group 2:}

The third worker completed the remaining work; therefore he should receive 360000: $18=20000 \mathrm{VND}$

- The total amount of the first two workers is: $360000-20000=340000 \mathrm{VND}$

- The total number of hours that they worked was: $t=7+4+2.4=19$
- The amount of money that the first person can receive is $\frac{340000}{19} \cdot 11=197000 \mathrm{VND}$

The amount of money that the second person can receive is $\mathrm{T}=340000-197000=143000 \mathrm{VND}$

Explanation of Group 2: All of them have the same idea, calculate the total working hours of three people, then calculate the pay for 1 working hour. The amount of wages for each person is easily calculated by multiplying the number of hours worked by the amount paid per hour. All three students in the group did not care about the productivity of each worker individually (meaning that three workers were equally productive).

\section{SOLUTIONS FOR NOTE 2}

Only Group 1 has the answer for the requirement of Note 2.

\section{NOTE 2: SUGGESTIONS OF PROBLEMS IN THE REAL CONTEXT AND RESOLUTION}

\section{Group 1:}

Case 3: (Saving material) building a house needs a lot of iron. The workers cut many pieces of iron of the same length. Specifically, the worker said that to build the pillars they need to cut the $6 \mathrm{~mm}$ diameter iron into 1000 segments with the same length of $0.7 \mathrm{~m}$ (for the main columns); 2000 segments equal to $0.5 \mathrm{~m}$ (for the auxiliary columns). However, observing the workers, it is easy to see that the workers cut iron arbitrarily and did not know the required iron amount. They bought a series of iron rods with a length of $7.4 \mathrm{~m}(7.4 \mathrm{~m}$ is the length of iron rod set by the manufacturer). The number of segments of iron is cut excess, causing a waste for the homeowner. Help the workers estimate at least how many $7.4 \mathrm{~m}$ iron rods are needed to cut following the required quantity?

\section{Solution of Group 1:}

For this matter, it is necessary to cut the required number of segments: $1000 \times 0.7 \mathrm{~m}$ and $2000 \times 0.5 \mathrm{~m}$ segments and we need to calculate so that the number of $7.4 \mathrm{~m}$ iron rods used is the least.

It is supposed that we cut each $7.4 \mathrm{~m}$ iron rod into $a$ $0.7 \mathrm{~m}$ segment and $b 0.5 \mathrm{~m}$ segment without residual $\rightarrow 74=7 a+5 b \rightarrow 7 a \leq 74$ and $5 b \leq 74$

Because $7 a \leq 74$ so: $0<a \leq 10$

Because $5 b \leq 74 \rightarrow 0<b \leq 14$ and $b=\frac{74-7 a}{5}=$ $15-a-\frac{2 a+1}{5}, b$ is natural number

So $2 a+1$ is divisible by 5

$0<a \leq 10 \rightarrow 0<2 a+1 \leq 21$ deduce

$\left[\begin{array}{c}2 a+1=5 \\ 2 a+1=15\end{array} \rightarrow\left[\begin{array}{c}a=2, b=12 \\ a=7, b=5\end{array}\right.\right.$

Therefore, there are 2 ways to cut sparingly

Method 1: Cut into 2 segments of $0.7 \mathrm{~m}$ and 12 segments of $0.5 \mathrm{~m}$ 
Method 2: Cut into 7 segments of $0.7 \mathrm{~m}$ and 5 segments of $0.5 \mathrm{~m}$

Now we choose the most economical way to cut

Let $x$ be the number of rods to cut following the method 1 and $y$ is the number of rods to cut following the method 2 .

So the number of segments of $0.7 \mathrm{~m}$ is: $2 x+7 y$ and the number of segments $0.5 \mathrm{~m}$ is: $12 x+5 y$

As required: $\left\{\begin{array}{c}2 x+7 y=1000 \\ 12 x+5 y=2000\end{array} \rightarrow\left\{\begin{array}{l}x=121 \\ y=108\end{array}\right.\right.$

So we can cut:

$2 x+7 y=2.121+7.108=998$ Segments of $0.7 \mathrm{~m}$

And $12 x+5 y=12.121+5.108=1992$ Segments of $0.5 \mathrm{~m}$

1 more segment need to be cut following method 1 is enough.

Then we use: $121+108+1=230$ segments of $7.4 \mathrm{~m}$

The total length of the cut segments: (0.7).1000+ (0.5). $2000=1700 \mathrm{~m}$

We can see $1700:(7.4) \approx 230$ rods.

So we have to cut 122 segments following method 1 and 108 segments following method 2. At least 230 rods will be cut, it's the most economical.

\section{Findings}

After testing the methods: "From problematic situations, practice for students to assess and select the solutions that are suitable for the real context”, relies on Rubric to assess students' progress in mathematical modeling skills (Table 2), we have the following comments:

For both Group 1 and Group 2, students also have strengths, that is, students have a passion for participating in specific problematic situations. However, the problem-solving ability of each group is different in the way of giving solution and their perceptions after solving it.

For group 2 (the group is not affected by the proposed method in the study), students solve situations that are mostly mathematical, lack of creativity when proposing solutions. Moreover, they have not yet seen whether the solution is appropriate in the practical context or not.

Group 2 does not perform the selection of solutions and does not consider the solution that the group has given to work in practice or not.

For Group 1 (the group influenced by the author's proposed measure into the learning process), we see a significant increase in mathematical modeling capacity in general, specifically, the students in the group can turn this practical situation into a mathematical task, thus, in our opinion the goal of increasing ability of converting everyday language into mathematical language and vice versa has completed. Students enthusiastically discussed, proposed a number of strategies for problem solving, assessed strategies, selected and coordinated appropriate strategies for problem solving.

An impressive point in the results of group 2 is that students not only come up with solutions to solve math problems, students have also considered solutions against real results, considered whether this mathematical result could be converted to practice and applied in a specific context? Students are confident to communicate, propose ideas for model improvement, change solutions, find acceptable options in best practice. Obviously, the goal of teaching math not only helps students acquire mathematical knowledge, the goal is to use their knowledge and life experiences to solve practical problems.

Thus, we evaluate that for group 2 including students who are affected by the proposed measures, there is a development in mathematical modeling ability in particular, improving math learning results in general.

\section{Conclusions}

This study aims to evaluate student problem-solving processes in their lives. In the research, it was found that the obtained answers were divided into two topics: unrealistic solutions and practical solutions, in which the group of students was not trained in Mathematic modeling was unable to provide a practical solution. For the group of students who have been fostered in the ability to Mathematic model in the teaching process, they have solved situations close to teachers' expectations. These findings coincide with those obtained by [16], [17], [18], [19].

In studies done by Verschaffel et al. [20], [21], it was found that the majority of school students achieved good mathematical results but were unable to interpret the results in Real-life circumstances, this suggests that the relationship between mathematics and real life needs to be improved from an early age [22], [23].

According to another finding of the study, students who are unable to come up with a practical solution prefer a concise approach (such as existing algorithms, existing formulas and only applying with little variation) mentioned by Hegarty et al. [24]. In addition, students are able to come up with practical solutions that have solved problems with their mathematical knowledge and hands-on experience. This finding is similarly mentioned in [25], [26], [27], [28], [29] and [30].

Students who provide practical solutions prefer the meaningful (case-based) approach mentioned by Hegarty et al. [35] It was observed that such students were able to scrutinize problem situations in real-life situations, identify the consistent and contradictory points of the results they achieved, and pose new problems to remove the inconsistencies they have identified, knowing how to access more information needed for the solution of the problem they posed and logically turned the problem into 
mathematical symbols. The findings obtained in this study coincide with those performed in [32], [33], [34], [35] and [36].

In Vietnam, there have not been many studies applying modeling methods in teaching Math in schools. In fact, few math teachers use mathematical modeling in teaching and learning, the explanation for this phenomenon is mainly due to the habit of traditional teaching methods; there is no strong motivation to change teaching methods. The current curriculum and teaching methods has not yet helped students understand the practical applications of mathematics.

However, I still find that teaching mathematics modeling in high schools in Vietnam in the coming period is promising. Because Vietnamese education is changing according to the general trend of modern education in which modeling is part of modern teaching.

Experimental results show that: Students in the experiment process are more interested in learning; they understand more lessons and the ability to apply the knowledge of Mathematics in general and Algebra in particular to solve real problems. The lessons associated with mathematical modeling always create a lively atmosphere for students because they are more excited to study, think, and discuss. This shows that the proposed measures are effective.

\section{REFERENCES}

[1] Preservice teachers' performances at mathematical modeling process and views on mathematical modeling. Procedia Social and Behavioral Sciences. Volume 2, Issue 2, Pages 4622-4628. https://doi.org/10.1016/j.sbspro.2 010.03.740

[2] Blum, W. (2002). ICMI Study 14: Applications and modelling in mathematics education - Discussion document. Educational Studies in Mathematics 51, 149-171. https://doi.org/10.1023/A:1022435827400

[3] Werner Blum, Peter L. Galbraith, Hans-Wolfgang Henn, Mogens Niss (Eds.) (2007). Modelling and Applications in Mathematics Education. New ICMI Study Series, Vol. 10 Springer 2007. ISBN-10: 0-387-29820-7

[4] Wu, M., Adams, R. (2006). Modelling mathematics problem solving item responses using a multidimensional IRT model. Math Ed Res J 18, 93-113. https://doi.org/10.1007/BF0321 7438

[5] N.H. Hau, T.V. Cuong, T.T. Tinh. (2020). Students and teachers' perspective of the importance of Arts in STEAM education in Vietnam. Journal of Critical Reviews. 7(11), 666-671. http://dx.doi.org/10.31838/jcr.07.11.121

[6] Nancy W. Denney (1990). 12 Adult Age Differences in Traditional and Practical Problem Solving. Advances in Psychology, ISSN: 0166-4115, Vol: 72, Issue: C, Page: 329-349. Publication Year1990. DOI10.1016/s0166-4115(0 8)60793-1
[7] Blomhøj, M. \& Hoff Kjeldsen, T. (2006). Teaching mathematical modelling through project work-Experiences from an in-service course for upper secondary teachers. Zentralblatt für Didaktik der mathematik, 38 (2), 163-177.

[8] Geary, D. C. (1994). Children's mathematical development: Research and practical applications. American Psychological Association. https://doi.org/10.1037/10163-0 00

[9] Meerschaert, Mark M. (2013). Mathematical Modeling. Academic Press - Elsevier Science \& Technology Books (4th Edition (C) 2013). ISBN: 9780123869128

[10] Blum, W. et al. (eds.) (1989). Applications and Modelling in Learning and Teaching Mathematics, Ellis Horwood, Chichester.

[11] Blum, W., Niss, M. and Huntley, I. (eds.) (1989). Modelling, Applications and Applied Problem Solving-Teaching Mathematics in a Real Context, Ellis Horwood, Chichester.

[12] Nguyen Danh Nam (2016). Modelling in Vietnamese School Mathematics. International Journal of Learning, Teaching and Educational Research

Vol. 15, No. 6, pp. 114-126, May 2016

[13] Breiteig, T., Huntley, I. and Kaiser-Meßmer, G. (eds.) (1993). Teaching and Learning Mathematics in Context, Ellis Horwood, Chichester.

[14] Huntley, I. and James, G. (eds.) (1990). Mathematical Modelling - A Source Book of Case Studies, Oxford University Press, Oxford.

[15] Lesh, R., \& Doerr, H. M. (Eds.) (2003). Beyond constructivism: A models and modeling perspective on mathematics problem solving, learning and teaching. Mahwah, NJ: Lawrence Erlbaum Associates, Inc.

[16] Mustafa Ulu (2017). Examining the Mathematical Modeling Processes of Primary School 4th-Grade Students: Shopping Problem. Universal Journal of Educational Research, 5(4), 561 - 580. DOI: 10.13189/ujer.2017.050406.

[17] Tiya Syahtriya Ningsih, Abdurahman, Djemari Mardapi, Suritno Fayanto (2019). Study on the Effect of CORE (Connecting, Organizing, Reflecting and Extending) Learning Model on Mathematics Learning Outcomes of Cognitive Domain. Universal Journal of Educational Research, 7(11), 2463 - 2471. DOI:10.13189/ujer.2019.071 125

[18] Blum, W., \& Leiss, D. (2005). „Filling Up “-the problem of independence-preserving teacher interventions in lessons with demanding modelling tasks. In CERME 4-Proceedings of the Fourth Congress of the European Society for Research in Mathematics Education (pp. 1623-1633).

[19] Blum, W., \& Ferri, R. B. (2009). Mathematical modelling: Can it be taught and learnt?. Journal of mathematical modelling and application, 1(1), 45-58

[20] Verschaffel, L., Greer, B., \& De Corte, E. (2000). Making sense of word problems. Lisse, The Netherlands: Swets and Zietlinger.

[21] Verschaffel, L., De Corte, E., \& Vierstraete, H. (1999). Upper elementary school pupils' difficulties in modeling and solving nonstandard additive word problems involving ordinal numbers. Journal for Research in Mathematics 
Education, 30(3), 265-285.

[22] Şahin, N. (2014). İlkokul 4. sınıf öğrencilerinin model oluşturma etkinlikleri üzerindeki düşünme süreçleri (Yüksek lisans tezi). Ondokuz Mayıs Üniversitesi Eğitim Bilimleri Enstitüsü, Samsun.

[23] Sahin, N., \& Eraslan, A. (2016). Modeling Processes of Primary School Students: The Crime Problem. Egitim Ve Bilim-Education and Science, 41(183), 47-67.

[24] Hegarty, M., Mayer, R. E., \& Monk, C. A. (1995). Comprehension of arithmetic word problems: A comparison of successful and unsuccessful problem solvers. Journal of Educational Psychology, 87, 18-32.

[25] Andersson, U. (2010). Skill Development in Different Components of Arithmetic and Basic Cognitive Functions: Findings from a 3-Year Longitudinal Study of Children with Different Types of Learning Difficulties. Journal of Educational Psychology. Vol. 102, No. 1, 115-134

[26] Byrnes, J. P., \& Wasik, B. A. (1991). Role of conceptual knowledge in mathematical procedural learning. Developmental Psychology, 27, 777-786

[27] Baroody, A. J., Feil, Y., \& Johnson, A. R. (2007). An alternative reconceptualization of procedural and conceptual knowledge. Journal for Research in Mathematics Education, 38, 115-131.

[28] Boaler, J. (2001) Mathematical modelling and new theories of learning. Teaching Mathematics and its Applications, 20(3), 121-128

[29] English, L. D., \& Watters, J. (200). Mathematical modeling in the early school years. Mathematics Education Research Journal, 16(3), 59-80.
[30] Mousoulides, N. (2007). A modeling perspective in the teaching and learning of mathematical problem solving (Doctoral dissertation, University of Cyprus, Cyprus). Retrieved from http://lekythos.library.ucy.ac.cy/handle/107 $97 / 5927$

[31] Hegarty, M., Mayer, R. E., \& Monk, C. A. (1995). Comprehension of arithmetic word problems: A comparison of successful and unsuccessful problem solvers. Journal of Educational Psychology, 87, 18-32

[32] Sahin, N., \& Eraslan, A. (2016). Modeling Processes of Primary School Students: The Crime Problem. Egitim Ve Bilim-Education and Science, 41(183), 47-67.

[33] Blum, W., \& Leiss, D. (2005). „Filling Up “-the problem of independence-preserving teacher interventions in lessons with demanding modelling tasks. In CERME 4-Proceedings of the Fourth Congress of the European Society for Research in Mathematics Education (pp. 1623-1633).

[34] Blum, W., \& Ferri, R. B. (2009). Mathematical modelling: Can it be taught and learnt?. Journal of mathematical modelling and application, 1(1), 45-58.

[35] Schapp, S., Vos, P., \& Goedhart, M. (2011). Students overcoming blockages while building a mathematical model: Exploring a framework. In G. Kaiser, W. Blum, R. B. Ferri, \& G. Stillman (Eds.), Trends in teaching and learning of mathematical modelling: The 14. ICMTA Study (pp. 137146). New York, NY: Springer.

[36] Wijaya, A., Van den Heuvel-Panhuizen, M., Doorman, M., \& Robitzsch, A. (2014). Difficulties in solving context-based PISA mathematics tasks: An analysis of students' errors. The Mathematics Enthusiast, 11(3), 555584 